Portland State University

PDXScholar

1974

\title{
Re-evaluation Co-counseling and the Treatment of Peptic Ulcers
}

Jack Justin Heims

Portland State University

Follow this and additional works at: https://pdxscholar.library.pdx.edu/open_access_etds

Part of the Social Work Commons

Let us know how access to this document benefits you.

\section{Recommended Citation}

Heims, Jack Justin, "Re-evaluation Co-counseling and the Treatment of Peptic Ulcers" (1974).

Dissertations and Theses. Paper 1754.

https://doi.org/10.15760/etd.1753

This Thesis is brought to you for free and open access. It has been accepted for inclusion in Dissertations and Theses by an authorized administrator of PDXScholar. Please contact us if we can make this document more accessible: pdxscholar@pdx.edu. 
RE-EVALUATION CO-COUNSELING AND

THE TREATMENT OF PEPTIC ULCERS

BY

JACK JUSTIN HEIMS

A report submitted in partial fulfillment of the requirements for the degree of

MASTAR OF

SOCIAL WORK

Portland State Univarsity 1974 


\section{TABLE OF CONTENTS}

Chapter I. - Introduction..........................pag- 1 Psyche or Soma?..........................page 1 Fept1c Ulcer- Physical and Fiscal Aspects........page 4 Psychologicel Factors.......................page ? Present Treatment of Peptic Ulcers...............page 10

Chapter II. - Theories of Fsychological Et1ology.........page 14

Chapter III. - Re-evaluation Co-counseling..............page 26 Theoretical Framework......................page 26 Re-evaluation Co-counsaling Explanation

of Psychosomatic Disease..................page 28 Fresent Application of Theory ................page 29 Comparison with other Theories.................page 30 Froposed Re-evaluation Co-counseling for

Eoptic Ulcer Pstients.....................page 33

Comparison with other Treatments..............page 35

Proposed Research........................page 38

Chapter IV. - Summary and Conclusion...................page 39

Bibllography...................................................... 40

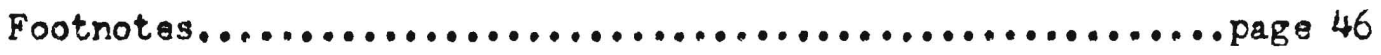


CHAFTER I - INTRODUCTION

For throe thousand years, the healers of the sick have debated the role that the psyche plays in the otlology and the pathogenesis of somatic dysfunctioning. The debate rages on with viable arguments on both sides (psychogenesis or straight disease approach). That the dobate still exists has afforded this paper wth a hollstic bias..

The topic of this paper, psychotherapy of peptic ulcer patients, initially has been concerned with the current status of the aforementioned debate. The body of this practicum will discuss the theoretical psychological approaches for the control and/or cure of that disease. Finally. It will entertain a new approach, Re-ovaluation co-counseling, peer cathartic therapy.

\section{Psyche or Soma?}

The concept of totality of the body has been vital in treating the patient with the peptic ulcer, a disese often stereotyped as the psychosomatic disorder. Since the alimentary tract is a system which the mind utilizes with great predilietion to relleve its own myriad emotionel tensions, the psyche has been incorporated into a definition of disease. ${ }^{1}$ 
Disease is the reaction of the organism, as a whole, responding to external or internal stimull that seriously liters its equilibrium. ${ }^{2}$. There is simply no dualism, for every pathom logical process has its organic and pyychic components, since It 18 aroduct of the psychosomatic unity. Unfortunately, in Western society, the term psychosonatic has negative connotations and has therefore been avolded somewhat in medical circles, thus adding an additional fuel to the heated debate of the role of the and in the disease process.

Dr. Frans Alexander, the founder of modern psychosomatic modicine, in listing the fectors of etiological importance in disease, has supported this holistic view by showing a balance botween the possible somato and psychogenetic factors: 3
a. hereditary constitution
b. birth injuries
c. organic diseases of infancy which increase the vulnerability of cortain organs
d. nature of infant care (weaning habits, toilet trai- ning. sleeping arrangements, etc.)
- accidental physical traumatic experiences of child- hood and infancy
f. accidental emotional traumatic experiences of child- hood and infancy
8. motional climate of family and specific per- sonality traits of parents and siblings.
h. later physical injuries
1. Later emotional experiences in intimate and occu- pational relationships

Thersfore, only consideration of all these factors and their interaction would afford a complete etiological picture of any disease. In particular, peptic ulcers. Naturally, empirical evidence of this psychosomatic unity 
has boen most difilcult due to the biss and training of the observer. A recent and reliable study was undertaken by B.I. Lewls at Johns Hopkins Hospital and reported in the "Journal of the American Medical Assoclation." In carofully studying 163 consecutive patients, Lewls found 498 had psyohogentc disorders alone and $27 \%$ had a combination of psychic and somatic processes. Therefore $76 \%$ of the studied petients were suffering totally or in part from an emotionally determined diserse. The medical problems of these 163 were predominantly chronic in nature, yet not sufficiently severe as to require hospltalization. 4

That the mind rules the body, has been, in spite of its neglect by blology and medicine, the most fundamental fact known about the process of $11 f 0.5$ Yet treatment for disease such as peptic ulcers has generally worked backward from the symptom. The sore has been the trouble, so the internist efthor soothes It whth an alkaling diet or cuts it out or severs the vagus nerve which carries the offending message to the mind. True, this may heal the sore itself, but the permanent solution has been to stop the sequence of events that lead up to that ulceric sore, otherwise the disequilibrium will surface in the form of another disease, 1.e. colitis. Hedicine today would do woll to take a look at history wiere relationship tetween the mind and the somatic disorders have long been known. For Instance, In 640 B.C. Hippocrates was roported to have cured King Ferdicas of Macedonis of a gastro-intestinal disorder by the analysis of a dream. 6 Iven the philosophar Flato addressed 
this topic by stating. "For this is the great error of our day. that physiciens seperate the soul from the body."?

If medicine today had followed Plato's words, there would be simultaneous and coordinated use of somatic (physlological. anatomical, pharmacological, surgery and dietary) methods and concepts on the one hand, and psychological methods and concepts on the other, thus creating asychosomatic method of approach to disease. 8 Due to the nature of the field of social work, this paper w1Il only address the psychological concepts and present a new psychological method to the trestment of peptic ulcers. One can only hope that ressarch of this nature will soon be coordinated with the somatic methods and research. Unfortunately, as of this writing, this coordinated approach is hardly existent.

Thus the answer to the "psyche or soma" question remains confused and only the diseased may continue to suffer because of the lack of coordination of the medical fields.

\section{Feptic Ulcer- The Physical and Fiscal Aspects}

The torm poptic ulcer is a genoral heading for both gastric and duodenal ulcers. ${ }^{9}$ An ulcer is related to the appearancs of gastric juices which create lesion when the ulcorating powers of the gastric juices (particularly hydrochloric acid) overpower the defense mechanisms of the stomach and duodenum (particularly mocus). When laft untranted and with contimed hyporfunctioning of this area of the gastrointestinal tract (hypersecretion, hypermotility, and hyperaemiz), the lesion becomes a 
hole In the wall of the stomach.

The functioning of the stomach is controlled by the autonomous nervous system, division of the peripheral nervous system vis the ragus nerve. Although its fuattonsarse carried out bolow consclousness, It is highly integrated into the structure and function with the rest of the norrous system. It serves the emotional, unconscious and autonomic needs of the various specialized systems, espocially the viscera. These needs for expressing distress or exaggerations of normal functioning aro converted into characteristic physical signs. 10

Fopular speach has recognized the powers of the autonomic systom in such sayings as, "I admired the guts he displayed in that act." or "I cannot stomach that behavior." or "I cannot swallow that movie." and et cetera.

Imotions are tied to the autonomous system through endocrine glands, enzymes and homones via the hypothalmus. The teams of iratts and Fulton, and Huff and Shoehan found that when the hypothalmus was excited it resulted in the release of gastric Juices of the parletal cells in the stamach lining. Opper and Zimmerman found concombttant with disease of the midbrain wero erosions of the stomach lining. 11 After 165 obsarvations of 26 patients (13 of which had ulcers, 13 control). Mittleman, wolff and Scharf ${ }^{12}$ revealed the following association of affective reactions and the chysiolopical furctions of the stomen:

"Tonsion, anxiaty, ressntriant, हuilt, obsaquiousnoss, and desparation already present, accentuated or induced wers almost always accompanied by an increase in hydro- 
chloric acid, musus, and pepsic secretions. Peristaltic activity became continuous and contractions increased in magnitude."

of Dav1es'13 205 chrontc ulcer patients, $84 \%$ had symptoms starting diroctly aftar emotional traumatization.

Hereditary is also a factor in the prodisposition to poptic ulcer. 14 Bauer found that chrontc diseases of the stomach were discorered three times as frequently in families of patients with peptic ulcers than the control. H.H. Rieker, 15 in twin studies conflrmed the role of hereditary factors. Howover, $H$. Necheler 16 hes raised the point that what might be thought of as hereditary may be simply eating, rearing and living habits. However, the general concensus among the more noteworthy researchers, namely Alexander and Dunbar 17, support hereditary as bolng a factor especially when one considers the stomach as being weekened by hereditary factors.

Sex was seen as a factor in ulcers. Prior to 193618, men dominated the disease of ulcers. Today however, both sexes are about evenly susceptable. The current ratio is 2.8 males to 1 femalo. 19

Ingestion of drugs has also been attributed to the etfology of ulcers. "The British Journal of Nedicine" has stated that $50 \%$ of ulcer patients were alcoholics 20 . One Denish study by W. Hojer-Federson ${ }^{21}$ has shown $18 \%$ drug addiction in peptic ulcer pationts. Aspirin addicts were noted as having high incidence of poptic ulcers.

Thus one begins to sense the multicausality of peptic ulcers, 
whether it be the inbalance of the entire nervous system, hereditary factors, drugs or other diseases of the gastrointestinal tract that weaken the stomach. The psychologicel causes will be discussed later in this section. There is simply no single causal agent in the atiology of this syndrom, 22

Statistically, peptic ulcers in the Unt ted States has beon a wide spread phenomenon. It has affected twenty million or approximately $10 \%$ of the population. Annually it kills ten thousand. Operative intervention is necessary in 15-20\% of the cases; eventually four million will have surgery. 23 From 1957-1965 there was a $40 \%$ increase in the estimated number of persons affected. 24 Mortality rates have been reported 25 high as $58 \% .25$

The total costs due to peptic ulcers nearly exceeded one billion dollars in a Rand study don in 1960,26

$\begin{array}{ll}\text { total disability costs } & \$ 463 \text { million } \\ \text { total death costs } & \$ 355 \text { million } \\ \text { total modical costs } & \$ 186 \text { million }\end{array}$

200,000 per year have been totally disabled for more than one wook. 27 In 1965, peptic ulcers were the twelfth most frequent cause of absenteeism and the fifteenth most frequent cause of death. Ulesrs have been a frequent subject for humerous inference. It clearly deserves more serious attention.

\section{Peptic Ulcers- Esychological Factors}

Due to the very nature of the human mind, the psychological factors involved in peptic ulcers are highly complex and research findings contradictory. Since the mphasis of this paper is on 
psychological concepts and methods concerning the psychic processes involved in peptic ulcers, this particular section will deal primarily with recent research into the factors.

Chronte peptic ulcers are peculiar to one species, the homo sapiens, and even here does not occur with any frequency until subjacted to the influence of civilization. 28 Dr. M. Franz has felt that the rise of ulcers in the large cities has been due to modern culture disolving many existing social structures. 29 Sussner has felt that it has been a disease of the beginning of urbanization. 30 stress, however has seemed to be the main theme. Fortunately, ulcers have boen induced in animals for research purposes. In a recent "Scientific American", Welss31 had devised a means of assessing the importance of psychological variables apart from the impact of the physical stressors on the organism. For those rats that could predict the shocks received little ulceration. Those that could not, did. Therefore, in higher cognitive processes, feodback affects bodily stress reactions.

In another rat experiment, A. Mikhail and H.C. Holland 32 have found that active rats developod ulcers three times loss frequentily than caged rats. This finding has tended to give Sussner's hypothesis regarding ulcers and the rise of urbanization some sustenance.

Psychological testing has come up with several stereotypes far ulcer patients. M. Hamilton 33 found his experimental group scoring higher on the anxiety-guilt and depency scales and lower on the obsessional than the control. In two seperate studies, one by Silverstone and Kissinger ${ }^{34}$, the other by M. Erown et al ${ }^{35}$, the two research teams concluded that peptic ulegr patients were gen- 
erally passive-aggressive with dependent leanings. In 1956. Weiss ${ }^{36}$. In a study of the psychodynamics of poptic ulcers found conflicts associated with suppressed resentment, angor. 1it. and fear of helplessness. F.A. Jones 37 concluded the patients whth peptic ulcer "have a tendency to worry inwardly."

In another study, this time of 120 women with ulcers, the researchers had found $25 \%$ depressed and holding in their anger and 104 choerful and holding in their anger. 38 still another team, 39 concluded that the common emotional factor is a threatened or real loss (support, financial or emotional security) leading to depression, ropressed rage, diffuse anxiety or denial.

Even the Forschach test has been utilized: 40

$88 \%$ of ulcer patients vs $26 \%$ of control had passive-oral tandencies $92 \%$ of ulcer pationts vs $56 \%$ of control had father fear $92 \%$ of ulcer patlents vs $32 \%$ of control had strong repression

Finally, in a Swodish test. A.I. Steinback ${ }^{41}$ found of 30 patients. all had experienced anxiety reactions in the last three months bafore seoking medical help for their ulcers.

From all these finding, one might conclude that anxiety has been the most indicated mental state. 42 It should bo noted that the typical motional constellations found in patients suffering from ulcers have also been obseryed in patients who do not suffer from ulcers, for instance those with heart disease. 43

As strong as the arguments have been for a stereotyped personality, typified by the hard driving executive who pushes himself too hard, rastrains in emotions 45 and wears his peptic ulcer as a 
badge of success, there are equally strong arguments that there is no stereotype. Both G.F. Balion 45 and M.I. Grossman 46 mave shown quite conclusively that peptic ulcers are not restricted to any definite age or that any definte personality type or personality typical of peptic ulcers have been established. Michael Futter concludes in this manners

"It appears clear that in spite of many claims to the contrary, patients with peptic ulcers do not have a specific personality pattern. However, it is probablo that anxiety traits are commonly associated with the presence of poptic ulcer than would be expected." 47

All of the aforementioned personality characteristics could be categorized under mental dysfunctioning. Here again the family has come into the etiological picture. In the "Journal of Fsychosomatic Niedicine". Gerdt Wretmark 48 has reported that $78.9 \%$ of his ulcer patients vs. $54.7 \%$ of the control group had one or more siblings and/or parents with mental disease. Fathers had a great frequency of alcoholism and mothers were commonly found to be neurotics in the experimental group.

Thus, due to the present confusion and the difficulty of defining and measuring psychological aspects of an ulcer, it has boen hard to tell what roles the personality plays in ulcers. It has been consqquently difficult to establish a psychotherapy to treat all ulcer patients. It has been the bolief of this author that Ro-evaluation co-counseling could woll be the answer to this dilomna. This particular therapy w11l bo discussed at length in a subsequent chapter. 
Due to the vagaries of peptic ulcer, particularly when one hes boen trying to appratse the value of any facet of medical trestment have been such that dogmatism on the part of this author has been avoided. This seotion merely has spoken to the comon method(s) of treatment utilized by modern medicine. 49

Dr. Sequin 50 has Iisted the four basic goals of treatment for ulcer patients in order of prioritys

1. Decrease gastric julces

2. Influence the upper center of neurovegative control

3. Act upon neurovegative inbalance

4. Handle the basic emotional conflicts

These four goals have been widely accepted in the medical field. Usually there is Iittle question of when a patient has an ulcer for the use of the X-ray and endoscope have brought the accuracy of a correct diagnosis to greater than $90 \%$. 51 An examination of each of the current four goals is useful in understanding today's medical practice.

\section{Decrease gastric juices}

Currently this has been done in throe ways: diet, antacids, and X-ray therapy. Since $20 \mathrm{~A} . \mathrm{D}$. when Celsus prescribed bland diets for patients with gastric distress, diet has been the routine recommendation by physicians to their patients with peptic ulcers. Today the diet is termed sippy after the doctor who created it in 1915.52 The essential pert of an ulcer has tean the frequency of meals rather than the type of food which centors around milk products. This diet is questionable for there has been a subsequent high incidence of atherosclerosis and the diet itgolf is environmentally frustrating in axd of itself, causirif undesiratle extra tenstion. 54 
Antacids are the mainstays of therapy. 55 All have their drawbacks. Calcium carbonate (Tums) has boen the most effective but has carried a danger of renal calcull. Alumintun hydroxido (Maslox) has had the denger of phosphate depletion syndrone or silicate stones. Licorice glycose has had the effect of stimula-: ting the secretion of protective mucus but has had no effect on decreasing gastric secrotion.

$X$-rays do not reduce acidity, but there has been a danger of cancer. 56 Peptic ulcer trestment has also been faced with many ephemeral cures. One such cure that has been recently popular and suddenly unpopular, has been the freezing of the stomach with $-20^{\circ} \mathrm{C}$ alcohol. 57 Another has been done on the part of Ir. David Sandweiss 58 who infected distilled water into his patients wh great enthusiasm for the dmug and got a $70 \%$ cure rate. Vitamin $A$ has Been also tested for it maintains the integrity of macus secroting cells. 59

\section{Influence the Autonomous Nervous System}

This portion of the general therapy has usually utilized such psychotropic drugs as bromides, barbiturates and the popular anticholinergic drugs. The latter decreases the release of gastric juices from the antrum and decreases gastric mobility, but some Individuals will develop blurring of vision and dryness of the mouth. 60

Thus the common route for on ulcer patient has been a sippy diet, antacids, and anticholinergic dmigs.

3. Neuro-vegative inbalances

This has called for surgical treatmert, sither a hamigastrec- 
tomy which removes $40-60 \%$ of the portion of the stomach which has the acid secroting parietal colls 61 , or vagotony which is a resection of the bundle of nerves that control stomach functioning. There has been greater chance of death in gastrectomy than vagotomy and less recurrence in gastrectomy than vagotomy. 62 Naturally, surgery has done little good without the removal of the underlying anxiety.

4. Handling the basie emotional conflict

It would appear the extensive application of psychiatric treatment has been awalting a generally accepted theory of ulcer causation. One study in 1952 showed that $80 \%$ of psychoanalysts had had no ulcer patients.64 Analysis has been of course an expensive and lengthy proposition. One thousand hours of analysis has not been unusual for cure. 65 Dr. E. Palmer treated 400 patients with psychotherapy alone, no diet or dmgs. 66300 were oured. 95 required further treatment and 5 dropped from therapy. Apparently the time and expense may be worthwile.

Another mears of handling the conflict has simply been hospitalization. This has indeed removed the patient from his or her source of anxiety and has generally healed the sore. However. It has been an expensive process and upon discharge, the patient must return to the orifinal anxiety producing environment. inedical doctors also have seen their own actions as substitute mothers (i.e. milk diet prescriptions) allowing the patient to yield to his passive-oral tendencies without an internal or external strugglo. 
CHAPTER 2 - THEORIES OF PSYCHOLOGICAL ETIOLOGY

In the last sixty years, perhaps as many as one hundred theories concerning psychological circumstances related to the dovelopment of peptic ulcers have emerged. They all have shown conflictual and unconvincing evidence. for research in psychotherapy is at best a difficult and discouraging endeavor. The more respected and followed theorios are discussed in this chapter. S. Froud

The fathers of all the aforementioned theories were Joseph Erouer and Sigmund Froud, who in 1936 presented the theory of conversion in thoir Studios in Hysteria. 68 Frior to this research team, the only significant findings came from Pavlov and Darwin. Pavlov had shown that stress situations produced reactions of a highly individualized nature in dogs based on the character and experience of that canine.69 Darwin had drawn attention to the similarities of humans and animals during flight or fight in regards to heart pulse, blood sugar, respiration and et cetera. 70

Perhaps with the aforementioned foundation. Froud formulated his concept of hysterical conversion: "In hysteria, the unbearable idea is rendered innocuous by the quantity of excitation attached to it belng transmitted Into some bodily form of expression, a pro- 
cess for which I should like to propose the name of conversion."71 Ho had further seen this as a "mysterious leap from the psychic into the somatic." Modern medicine has taken objection to the latter part, feeling that this leap is no more mysterlous than any other motor innervations, such es voluntary movements or expressive movements such as laughter or weoping. 72

In discussion of this topic. Froud had been very definite on two counts: one, that a conversion was a symbolic substitute for an unbearable emotion, a kind of physical abreaction or equivalent of an unconscious emotional tension, and two, that all of the repressed emotion can be retraced to sexual tension. In Studies in Hysterla. Brouer and Froud have elted case after case supporting these two hypotheses, though none dealt with ulcers specifically.

Furthermore. Froud had seen that these substitute innervations never brought full relief, they were only attempts at relief. The remnant tension that was not relieved showed up in a pathological condition. 73 The important issue, naturally was that the anotional tension itself was partially relieved by the symptom itself.

Froud has presented a model of cathartic psychotherapy (with an overwhelming, analytical base) that alledgedly rids the clients of not only the romaining tension, but also the tension that Initially caused the pathological condition. of colirse, this model was drawn from his observation that when gmotions were not expressed through normal channels by voluntary activity, 1.0. rage, weeplng, that they became a source of chroric psychic and physical 
disorders. In making an analogy with cathartic and anslytical psychotherapy with the surgical removal of a pus pocket. Froud had stated, "Such an analogy finds its justification not so much in the removal of the morbid material as in the production of better curative conditions for the issue of the process." 74

This paper has assumed that the reader has had an understanding of cathartic and analytic psychotherapy, so it has not dealti with description of the techniques at this time. However, the following chapter dealing with Re-evaluation co-counseling has presented a discussion of Froud's techniques relative to cocounseling. F. Alexander

Soon after Froud's clarification of psychosomatic disease, the fleld was entered by Lr. Franz Alexander, whose widely published works including the establishment of the "Journal of Psychosomatic Medicine" have earned him the title of the "founder" of this figld. Alexander took Freud as a starting point in creating a second manner besides conversion in which mechanisms of integration may tecome pathogenic: vegative neurosis. 75

Alexander has restricted conversion phenomena as presented by Freud to symptoms of the voluntary neuromuscular arki sensory percoptive systems and difforentiated them from psychogenic symptoms in the vegstative organ systoms, those operated by the autonomous nervous system explainsd previously.

Alexander's rationale for this distinction has been that conversion symptons ware substitute expressions, abreactions or unexpressed emotional tensions. This mechanism has bean restricted to 
the voluntary neuromascular or sensory perceptive systems whose function has been to relieve and express emotions. An example would be paralysis of the larynx of a person who cannot find expresston of rage through yelling, accusing or hitting. On the other hand, Alexander has shown a vegetative neurosis consists of a dysfunction of a vegetative organ, controlled by the autonomic nerrous system, not the voluntary neuromuscular system. Thus the vegetative symptom is not substitute expression of the emotion but its normal physiological concomitant.

Alexander has assumed that for every motional stato, there has been certain distribution of vegetative innervations. For Instance. Pavlov found in his dogs that the attitude accompanying and preceding food intake and digestion was accompanyied by a vegetative tomus. If these emotional states ware chronically sustained, then the vegetative innervations (1.e, in the stomach - hypermotility, hyperacidity, atc.) also became chronic.

Interestingly enough. Alexander has deemed a peptic ulcer as boing "neither conversion symptom nor a vegetative neurosis. In some cases it has been the somatic end result of a long standing neurotic stomach dysfunction, but in itself has nothing whatever to do with any emotion. It has not been the symbolic expression of a wish or self-purishment. It has been a secondary physiological end result of a psychogenic functional disturbance, a vagetative neurosis of the stomach. 175

Another of Alexander's guiding principles has boon that physiologic charge itself has been relatad to a particular "emotional constellation". For instanca, ho stated that an ulcer patient is 
commonly diagnosed as having "frustration of the dependent, help soeking. love demanding desires". That the patient is further characterieed as a dependent person who must do nothing to lose approval of those he is or might be dependent. He therefore restrains himself from any show of anger, and consequently inhibits expression of his natural feolings and whes.??

Utilizing Froudian framowork. Alexander has had the opinIon that an ulcer patient has strong oral-receptive tendencies. He desires love and security. When a wish is not satisfied, these oral cravings become frustrated and that increases gastric secretion. One would think this would also increase ones' appettto. however, as A.J. Sullivan has polnted out in Fersonality in Poptic Ulcers 78 . there has boen no statistically significant gain in appotiteof weight in patients with poptic ulcers.

V.S. Baugh's 79 studies have afforded Alexander's guiding principle some substance. He has found that in repression of emotions. the diaphragm dies (arrests), thereby causing macosa of that area (the stomach) to have low vitality and low resistance to increased activity from anticipated love or its conditional equivalent - food.

A third guiding principle of Alexander's in regards to the psychosomatic dimensions of gastrointestinal and other disturbances has been the theory of spocificity. Alexander and his colleagues at the Chicago Fsychoanalytic Institute have favored the concept that different personality types and thus emotional tension affect different specific organs. Again, this has relatsd back to his holistic essumption. that the physlological responses to different tensions are varidi that, consequently, vegetative dysfunctions 
result from specific emotional constellations. Thus the symptom has only been one pert of a nourotic disturbance of that persomal1 ty. 80

Therefore, Alexander's general theoretical model may be expressed in the following terse manner, 81

1. All healthy and slck human functions are psychosomatic.

2. Imotions are always associated with concomitant action expressed through a portion of the autonomous nervous system and Its innervated organs.

3. For specific emotions there are appropriate concomitant vegetative patterns.

4. Those portions of the anatomy controlled by voluntary action are subject to the conversion phenomenon as opposed to the autonomic system which falls under the category of regetative neurosis.

5. Imotions repressed from overt expression lead to chronic tensions, thus intensifying in degree and prolonging the concomitant vegetative innervation in time.

6. The resulting excessive organ innervation leads to disturbance of function which may sventually end in morphological changes in the tissues.

F. Dunbar

Conccurrent with Alexander's publications was Dr. Dunbar's Mind and Body ${ }^{82}$, volume of eplc proportions that has covered 211 diseases in an annotated bibliographical form. She has, howevor, presented her brand of a conceptual model. It has been highly mechanistic, dealing in variable distribution of energy which has often beon disturbed by internal difficulties preventing adequate expression of foelings stirred up by life situations (again Froud's effect on conceptual models). Like Pavlov, she has belleved that whthout mora direct oxpression of action, the organ of preparation for such action must carry the task of dealing with the resulting 
tension or accumulation of energy, discharging it in dysfunotion or succumbing to it in the form of morphological change and wasting $1 t .83$

More current researchers have found fault with this shortcircult theory. Items such as the reversability of tissue damage, specificity and the organ as a total psychosomatic process have gone without mention in Dr. Dunbar's theoretical presentation. 84 However her aforementioned laws of emotianal thermodynamics as well as her development of psychological profiles of specific disease syndroms still have held wolght in setting current research diractions.

Wuch of her investigations into psychological profiles centered on disease of the gastro-intestinal tract. Spectfially regarding peptic ulcers, Dr. Dunbar found the stereotype of the ulcer patiert as being the go-getter was true. However she also found some Interesting stereotyped psychodynamics underlying that facade:

"The ulcer patient in his childhood usually is devoted to his mother, and yot he cannot be satisfied with the dependence which that devotion implies. As he grows older, he is continually torn between his impulse to lean upon his mother, wife, friend or employer and his compulsion to essert his own independence. It is his desire to escape from his own fear of being a clinging vine which causes him to reach out for ro sponsibility and gives him the appearance of the go-getter and often causes him to climb quite high in the ladder of worldly success.

There is not in this personality the drive to exeal which characterizes others, the coronary type for example. The ulcer patient's ambition and activity are merely a cloak for his dependent pull. He wants only to be active and escape from his own suspicion of inferiority; he does not necessarily seek to rival others, to climb over them, to impress his superior abilities upon them. 85 "

Iike the research of others. Dr. Dunbar's stereotype, based upon years of practice has supported Alexander's argument in that there 
has boen a hurt, the dopendence-independence conflict, that has a natural somatio concomitant - gastric irritability. H. Wolff

Harold Wolff, whose distinct theoretical position constituted a special position in the fleld, has borrowed somewhat from Pavlov's findings. Wolff ${ }^{86}$ has pointed out that stresses which affect man arise not only from his biological and physical environnent, but also from threats and symbols of past dangers, from failures and Irustrations of his needs and aspirations, and from cultural pressures and rapid social change.

To these stresses, the body assumes what wolff has termed a "protective reaction pattern." Innately, humans have created exergency protective patterns, preparing the body for mobilization by giving it extra fuel. When the crisis is offensive, stated Wolff. the stomach prepares by secreting added gastric juices to digest the food or symbollc ftem that will be consumed after the "kill." Along with these body preparations go certain feellngs and attitudes, which, stemming from the same needs have the same goals and same somatic results. Thus in later iffe, when one is restimulated by a hars and now omotional or environmental situation, he or she raacts by a patterned physical and psychological response. Thus the go-getter businessman is always out for the "kill" and consequently develops an vilcer. C. Soquin

In an attempt to consolidete wolff. Dunbar. Alexander, and Froud, Charles Saquin has left sut eny points of controversy from thess other four rasarchers and has remained fairly middlo of the 
road. He has felt that events that had interforod wh natural maturation and progress tand to mako an individual oscapo from the struggle and take refuge in dependence. Unconsciously that person would Ilke to become the child whose mother takes care. feeds and protects him. Due to social tenets, he cannot admit this to himself and creates a reaction formation, causing him to act over-agressive and independent. If the repressed desire for dependence contimues, it will transform (convarsion) itself into a desire to be fed. The stomach acts as if it is expecting food develops an ulcer. To the two mechanisms of integration which may become pathogenic, namely conversion and vegetative neurosis, Sequin adds a third, designated as "secondary effect" which basically is the culture and patient's own reaction to the disease 1tself. For example, many patients have ulcers that will heal in hospital and stay that way despite a roturn to the same hostile environment that caused it. F. Deutsch

Felix Dentsch gained acceptance as a viable theoretician in the fleld of frychosomatic medicine in 1962 with the publication of Sody, wind and the Sonsory Pathways ${ }^{88}$. its thesis has been that the real or imaglned loss of an object leads to symbolization of that objact. Somatimes, the sonsory pathways will reunify with the lost object (or symbol) and place in orto (1.e. skin disease) or into parts of the body. This leads to ar alteration of physiologic functions in the body such as uleers. S. Iachman Nost recentiy, psychosomatic disoriers have coma under the 
study of behaviorists, most notably Sheldon Lachman. 89 Although most of his presentation has been a rewording in behaviorial terms of the aforementioned theories, Lachman has presented a new set of theoretical perspectivos collectively termed autonomic learning theory.

The essence of this theory has been that "psychosomatic manifestations result from frequent or prolonged or intense implicit reactions elicited via stimulation of receptors." 90 A more simple statement would be that the role of learning of the development of psychosomatic aberrations is emphasized without minimizing the role of genetic or non-genetic predisposing factors.

Lachman has gone on to divide psychosomatic phenomena into three categories: The first was constructive psychosomatic reactions; those efforts on the part of the organism to combat illness or disease processes, 1.e. the increased blood pressure in those patients with low blood pressure. The second was destructive or pathological psychosomatic reactions. These might be those intense physlological changes induced by persistent emotional stimalation that are dysfunctiona 1. 1.e. asthmatic attacks. The third and last was simply psychosomatic diseasa; those organic pathologies resulting from sustained, repeated or intense reactions to emotional stimulation. In other words, Iechmar was addressing such permanent structural damage as ulcers and colltis. Furthermore, any structure or bodily function can be the end focus of psychosomatic phenomena. but Lachman has stressed. Iika Alexamer's vegetative neurosis, those that are directly innervated and regulated by the autonomous norvous system. 
Since motions involve the viscera and since the autonomous nerrous system has been the major mechenism for mediating omotional behavior, and since motional reactions may be learned. and last, since it has been these reactions, where sufficiently Intense or sustained can cause pathology then according to Lachman, these emotional reactions can be unlearned or eliminated. He therefore has proposed as one of the goals of psychotherapy for patients with psychosomatic complaints that the patient learn via behavior modification torantar contal in so far as possible over his own autonomous norvous system functioning and also the emotion arousing situations and conflicts that disrupt the patient's homeostesis. Also included in Lachman's brand of psychotherapy was educating the patient in the role of motions in any and in his particular illness and training him to avoid or constructively deal with omotional situations or conflicts that have operated negatively for him.

Finally, Lachman has arrived at an equation that represents a figure for psychosomatic breakdown

$$
B T=\frac{\text { Emotional activation }}{\text { Biological assets }}
$$

ET refers to breakdown threshold. Emotional activation refers to the value (duration, intensity and frequency) of the emotional arousal. And biological assets of course refers to the degree of blological strength or resistance to pathology.

Generally spoaking, this formula has tied all theories of psychosomatic disorder in that it represents tho holistic viow all biological disorders have psychological components 
and all psychological disorders have blological disorders thut mast be considared in both diagnosis and treatment. In other words, the human organten has been a payoho-soc10-b10-phystoal unst. 
CHAPTER 3 - RE-EVALUATION: CO-COUNSELING

This chapter has been developed to present the reader with an overview of remevaluation co-counseling and its possible application in the field of psychosomatic medicine. It has done so by first presenting the basic theoretical fremework, then by a discussion of how re-evaluation co-counseling might explain psychosomatic disease and also by a presentation of the present practice of this pear cathartic therapy. Furthermore, this ehopter has compared re-ovaluation co-cousneling to the theorles presented in the last chapteri a proposed ro-evaluation co-counsoling for poptic ulcer patients to the thorapies popular today. and finally proposes further research in this field.

Theoretical Framework

The theory of re-evaluation co-counseling was originated by Harvey Jackins in 1950 and in the last decade has boen published by its mentor in The Human Side of Human Beings. 91 This framework has served as a basis of practice that has become increasingly establighed in self-help groups in the United States and a doren foreign nations. 
The theory has essentially three conceptsi rationality, patterns and discharge. Jackins sees man es inherently having the charaoterlstics of vast intelligence, zestful enjoyment of IIving and loving, and having co-coperative interporsonal rom lationships. Furthermore, any behaviors other than these thres Innate characteristics is representative of something having gone wrong. That something gone wrong, says Jackins, is that people got hurt, elther physically or emotionally and this shuts down the flexible human inteligences rationality. This is rellected in expressions such as "scared out of my wits" or "so mad I couldn't think straight." Specifically, a rational act is one axactly created to suit a new situation, one that is unlike any other.

The opposite of a rational response to a new situation, the theory argues, is a patterned, repetitive response. Orie does not utilize his full intelligence by attempting to solve a brand now problem or situation with a past response to a similar situation, for ho is not taking into account the now elements. Addictions. panies, and nouroses are extrome examples of patterns. Stege fright. the infinite number of phobles, and sex roles are everyday examples of humans behoving in a patterned manner. He is unaware of any dysfunctioning and unable to fully control that situation.

The theory further presents discharge of emotional distress as the cure-all for the removal of patterns and irrational rosponses. Hurtful experiences can bo subdivideat into six categories with six corresponding innete discharge procosses. 
hurts

1. grior

2. foar

3. ang or

4. embarassment

5. boredon

6. physical discharge mechantsms

crying

cold sweat and shoking

warm sweat and stoming (tantrum)

laughter

non-repetitive talk

strotching, scratching and yawning

The theory further postulates that discharge is not part of the pain of the hurt as today's culture tends to belleve. "Don't cry, everything wII be OK." or "Stop shaking, get a hold of yourself, have one of my valiums, or a stiff drink, otc." Because soclety lays so many stigmas on these discharge processes ("big boys don't cryi stop crylng or I'll really give you something to cry abouts young ladies aren't supposed to show their anger.") poople establish non-discharge patterns; in other words, repressioninternalization. Furthermore, when discharge is allowed to happen, present or previously accumulated distress will be removed, rationality will be restored and the rigid behaviors such as phobles wIII be overcome.

Re-ovaluation co-counseling explanation of psychosomatic disease Ro-ovaluation co-counseling theory, though it does not deal specifically with psychosomatic disease, might well explain this phenomena in the following manner. As was mentioned previously. when one experiences physical (tension or injury) or emotional hurt, the flexiblo intelligence cesses to function. All inputs to the mind, whether internal or external, during these traumas are mistored unless discharge frees the storage mechanisa. This mistorage can show up at any point in the body. Re-evaluation 
co-counseling theory would go onto explain that discharge would decrease and eventually cure the physical sign of mistorage. For those that have experieneed discharge of a heavier lovel of hurt such as fear, anger or grief, they recall a sense of physical woll being. Obviously, this parallels the theories of Wolff and Dunbar.

\section{Present application of theory}

The practice of re-eveluation co-counseling involves recovering through removal of internal and external impediments and utilizing the natural discharge process. In the classes. students are trained to be sufficiently present for their clients so that he will feel safe to discharge. This entalls being an attentive and supportive 11stener, ane who refrains from making interpretations, ovaluations, criticisms, comparisons and giving advise. The counselors are also tralned to break those Internal impediments to discharge, control patterns (1.e. the grown man who is unable to cry because he was reared on maintaining a stiff upper 11p).

Meeting outside of class, two students take turns counseling and being counseled. The one acting as counselor listens, draws the other out and permits, encourages and assists enotional discharge. The one acting as client gets in touch with the hurts, past and present, discharges and consequently re-evaluates the stressful situation. 'ilth growing experience, confidence and trust, the process works incressingly better,

Thus one sees that the practice of ro-evaluation co-counseling 
does fill the mental health needs of America in that it is inexpensive, requires minimal facilities and training, is applicable to all ages, sexes, races and nationalities and is readily available.

Comparison with other theories

Although Harvey Jackins (a math major) had minimal knowledge of psychological theory, his re-evaluation co-counseling theory does have many similarities with the theories discussed in Chapter 2. The following discussion has dealt solely with thoory, not practice. for this has been discussed in a later portion of this chapter.

Anna Froud spoke of Sigmund Freud's belief that the cathartic method as he used it led to a "restored nervous system". 92 This restoration, thought Freud, would prevent the mysterious leap from the psychic into the somatic," in other words, conversion phenomena. He had folt that there would be no need for a symbolic substitution of an unbearable emotion if that emotion wore. in re-evaluation terms, discharged. Freud thus had relied heavily on catharsis, seeing it both as a symptomatic and causal therapy.93

Alexander has disagreed somewhat with the values of catharsis, seeing woeping as having no utility. 94 He has seen psychosomatic disease such as hypertension arising not from repressed but unexpressed emotions. Re-evaluation co-counseling would say that both cause pathology. However, Alexander has not seen Fraud's conversion as valuable.

"One of the most important discoveries of Freud was that when emotion cannot be expressed and relieved through normel channels 
by voluntary activity, it may become the source of chronic pscyhic and physical disorders. Whenever emotions are repressed because of psychic conflicts - that is to say. excluded from consciousness and thus cut off from adequate discharge - they provide the source of chrontc tension which is the cause of the hysterical symptoms." 95

Regarding the peptic ulcer stereotype, Dunbar has stated, "The ulcer patient's trouble is that he seldom realizes the true state of his amotions." She also has seon that when the person struggling with such conflicts es dependency-independency has brought the essential conflict to the surface of their mind and has began to grapple with it intelligently, then the ulcer will come under control. In other words, in re-evaluation language, the person gets hurt, deals wh th in the innate discharge manner and feels better. 96

Many other psychosomatic researchers have unknowingly supported re-evaluation theory. For instance, I. J. Sharron 9 ? has seen that abreaction as a release and relief of affect at the revival and reliving with intensity of a past traumatic ovent whether forgotten or remembered leads to a lessening of tension. a breaking up of abnormal petterns, uncovering of other repressed or forgotten material and facilitation of transference. Sharvon has differed from re-evaluation practice in that he utilized drugs to braak through the chrontc control patterns, whereas re-evaluation ca-counseling utilizes what is termed a "spectrum of techniques." Furthermore, Sharvon has done nothing for his clients in ramoving the guilt or anxiety that stem from such control patterns as "big boys don't cry."

I.J. Harris 98 . in his study of depressed womer has found that 
there is a close correlation botween inablity to express foelings of resentment and somatic dysfunctioning. He further has supported the pattern concept of ro-ovaluation co-counseling by stating that the perception of stress depends on the constitutional endoment and previous experiences of the individual. Moreover, he has stated. "A feeling of good health is dependent upon a gratification of basic noeds and upon an ability to dischargo: anger externally and rather completely." 99

Greenacre, 100 from the psychological studies of children, hes found that the early polymorphous discharge of tension leaves these channels available for discharge in later 11fe. Then, during periods of heightened anxiety, frustration and danger, the How of activity is conducted over old channels reviving the overflow responses of early 11fe; tharefore breaking patterns of control before they become chronic.

J.B. Kirsngr in his research on dundenal ulcers has shown that the removal of a source of irritation plus encouragement to express anger. frustration, resentment and tension may be more helpful than drugs in the control of ulcers.

Finally, Fercival Symonds ${ }^{102}$, in a study of successful psychotherapy in 68 cases, has found "59 followed abreactions, 7 followed interpretations by the therapist and 2 were related to change in perception which may or may not have been caused by the therapist's comments." He has gore on to say that. "It is quite posatble that in tho 9 cases in which the changes apparently followed the therapist's interpretation or were related to changes in the client's perception, the changes actually followed 
abreaction that was not noted or racorded by the thorapist. and it is possible that the abreaction might not even have been observable but might have been more in the nature of an intermal reaction."

Symonds even has paralleled the re-ovaluation co-counseling concopts of free attention as a necessity for discharge ("Insight I") and ro-evaluation of a distressful ovent of the past ("Insight II"). Symonds has stated, "Before abreaction can take place, the client must parceive the situation in a different way than he is accustomed to perceiving it, that is non-threatentng (notes what re-evaluation terms balance of attention, which is a balance between the awareness of the here and now with the therapist and the heaviness of the client's material)... Insight II depends upon a preceding abreaction which reduces tension, removes threats. and makes the chang in perception possible. Insight II paves the way for further abreaction (notes what re-evaluation therapy terms breaking of control patterns) which helps the therapertic process to proceed until the therapeutic goal is reached." It would sesm therefore, that both Symonds data and his interpretations support the practice of ro-evaluation co-counseling psychothorapy for those clients with psychosomatic disease.

Proposed Re-evaluation Co-counseling for Peptic Ulcer Patients

Due to the fact that reviluation co-ounseline has beer tested and perfected over the past twenty years in thousands of cases in nearly a hurdred seperate communities, this author has found attempts to chang the present structure of re-ovaluation co-couns ling unworthwile. The Ilenentary Counselors Manual 
has presented concise guide to the do's and don't's in the art of boing both a client and co-counselor. 103 This handbook combined with eleuntary classes in co-counseling can afford virtually any lay person the ability to counsel and be counselled by arson with peptic ulcersi with Iittle expense and theorotioally - maximum officacy.

In normal organization of groups, therapists attempt to have group composition of like people, for instance obesity. adolescent, cancer or married couples groups. It is suggested that this not be the case for a class in re-evaluation co-counseling for people with peptic ulcers. Since these clesses have been for cless members to re-evoluate their own material where the teacher plays only a minor role as therapist (por so), then the ulcer patients would only feed into each other's patterns rather than breaking that pattern (1.9. control pattern of repression of emotion). Therefore, if any ulcer patient found himself in a mixed group, he would have a high chance of getting a co-counsalor who would perceive that pattern and aid that client in brenking 1t. One must be aware in co-counseling that a pattern. like dmg addiction, will fight off all attempts to cure that pattern or acilction.

Therefore the proposed trestment for peptic ulcer patients utilizing re-evaluation comcounseling differs in no way from the status quo use of this therapy as outlined in the Eiementary Counselors lanual. Also, the Spring is sue of the Journal of Humanistic Psychology (1972) has prasentad two excellant articles by Dr. 
Thomas Scheff $\mathrm{f}^{104}$ and Dr. Bernerd Somers ${ }^{105}$ dealing with re-evaluaton co-counseling. Both have afforded a terse outline of this therapy.

Comparison of P.o-evaluation Co-counseling and other treatments

Contemporary psychosnalysts stress interpretation and

insight and tend to disregard catharsis. 106 They believe that Freud and Ereuer 107 tried cathartic therapy and found it wanting. In his work. Froud did indsed see abreaction as affording only temporary relief from somatic dysfunctional sysmptoms. From the re-evaluation counseling perspective, this was due to the incompletenoss of Froud's methods.

In treating his potients. Froud, as in re-evaluation cocounseling. alded them in gatting in touch with a traumatic event. Curs, he felt, came "with appropriate affect.. The patient is, as It were, getting rid of it by turning it into words. The patient only gets free from hysterical symptom by reproducing the pathogenic impressions that caused it by giving utterance to them with an expression of affect." Therefore, he and re-evaluation therapy both consider verbalization of trauma as essential, howerar. the latter would seg that words are a trigger for the discharge of amotions, not an and in 1tself. As was aforementioned, patterns such as those associated with paptic klears, are driven by a great reservoir of motional distross, distress requiring tens or even hundreds of hours of discharge. 108

From this point of viaw, then, 1t would sem that freud and those therapists who have followed his model have been only skimelng, the surfsce of the emotional distress of their clients. 
Re-ovaluation co-counseling sees Freud as further orring in oncouraging the pationt to forget the trauma that he had discussed, thus leaving the material still undischarged and probably recidivistic.

In a footnote to his discussion of the technique of abreaction of arrears (discharge). Froud had stated "I once learnt to $n$ surprise that an abreaction of arrears of this kind can form the subject of an otherwise puzzling neurosis."109 He continued by describing case in which the patient cried continuously under hypnos1s. He then went on to say that the depression from which she was suffering loft, bringing himself what he irontcally termed "credit of a great therapeutic success by hypnosis." when in actuality he was allowing the innate discharge mechanisms to operate.

Thus the central error made by Froud and his contemporary followers has been to focus on the verbal aspect of the cathartic experience. elicit discharge but then interfers with the very discharge process they had alicited by interpretation and steering the client to verbalization of feelings. A secondary error according to ra-ovaluation counseling would be that the psychoanalytic theraplst interprets the patient's own material for him or her in an authoritarian position. rather than allowing the client to gain sufficient froe attention via discharge to reova luate his or her own material by himself or herself.

Re-evaluation counseling differs greatly from the behavior1st's approach. Behavioristic techniques do not take into account the ro-evaluation counsaling terects of man's nature, rather treat 
man as a programed machine. Behaviorists only chang the overt Igne of a pattern and like an leeberg leave the great majortty of the pattern untouched, only to resurface later in another psychosomatic pathology. However, bohivior modification is used tacitly In re-evaluation clesses where clients who dischargo are given strokes for that act. On the other hand, behaviorists would have to admit that non-discharge due to control pattorns is also troated with varmth.

Another in-vogue therapy that also deals with catharsis has been that of Arthur Janov's "Primal Scream" therapy. 110 Although emphasis is on screaming. Janov has recognized other forms of discharge: "No two primals are alike oven for the same person. There are angry and violent ones, fearful ones, and quiet and sad ones. Whatever form it takes, the therapy is aimed at old unresolved foelines."111

But like Froud, Janov has made the error of cutting off discharge. "I began to cry more and Janov waited and then said, 'say what you're foeling. don't cry it away.' I stopped crying eventually and grew quiet." 112

Thomas Sohef $f^{113}$ has sean two fundamental differences in the approaches between re-ovaluation and Frtmal Scream. In the former therapy, the client is in cherge and therefors is allowed to go at his own pace and not be forcad into arans for which he is not ready. In trimal Scream, the theraptst is elearly in an authorative position and uses considerable force and coercion to meat the tharapist's axpectations. 
The second difference lies in Janov's opinton that the defenses constitute aystem wich must be overthrow all at once. Re-araluation co-counseling makes a contrery assumption that patterns constitute systeme that may be breached one at time, so that the therapy can be seen as a protracted, gradual and relatively. undisruptive process.

This paper will not attompt to deal with transactional ansiys1s. Howover. from what this author has soen of this therapy. it does share the humanistic characteristic of re-evaluation co-counseling, but the therapist, not the client, is again in charge.

\section{Proposed research}

As In any research Into a psychotherepy approach to the cure of peptic ulcers, conclusions are at best guarded due to the highly Individualized character of therapy. Treatment of patients with peptic ulcers by re-evaluation co-counseling would, however. provide "cleaner" research due to the commonality in the practice of 1t.

Some variables that might be tested would be placing several similar cases in re-evaluation, behavior modification, psychoanalytic or primal therapies and compare cure rates. Added factors might bo using or not using antacids, psychotropic drugs or surgery.

Finally, it would be interesting to masure stomech activity during emotional discharge. As was mentioned in the first chapter. this has been done with the measurament of acidity or motility of stomachs of patients in stress situations, but novar while discharging. 
CHAPTER 4 - SUMMARY AND CONCLUSION

This paper has served to discuss the present status of psychosomatic disease, specifically peptic ulcers and the the psychotherapios for thom, specifically introducing Re-evaluation co-counsoling into this field as a viablo, inexpensive, human1stic alternative. In disease such as peptic ulcers that is plagued by ephemeral and vogue cures, one looks very carefully at any innovation. Re-evaluation co-counseling comes to this field and brings with it compassion, a significant theory and successful methods at achieving control of the hurts that aight lead to peptic ulcers. 


\section{BIBLIOGRAPHY}

$\underline{B O O K S}$

1. Alexander, Franz, Fsychosomatic Specificity. Univ, of Chicago Press, Chtcago, III.. 1968.

2. Alexander, Franz, Studies in Fsychosomatic Medicine, Ronald Press, New York, 1948.

3. Bauer, Julius, Constitution and Disease, Gmine and Stratton. Now York, 1947.

4. Blumenthal. I.S., Resosrch and the Ulcer Froblem, Rand Corp.. Santa Monica, Calff.. 1960.

5. Brouer, Josef, Freud, Sigmund, Studies on Hysteria, Basic Books, Ine. . Now York. 1957.

6. Darwin, Charles. The Exprossion of Emotions in Man and Animals, Apploton and Co., Now York, 1896.

7. Davies, D. Wilson, M.. Observations on the life History of Chronic Peptic Ulcers, Lancet Fublishing house, London, 1937.

8. Doutsch, Felix, Body, Mind and Sensory Gateways, Basic Books, New York, 1963.

9. Dunbar, Flanders, Mind and Eody, Random Housa, New York, 1955.

10. Entralgo, Pedro, Nind and Body, P.J. Kennedy and Sons, New York.

11. Freud, S1gmund. The Qugstion of Lay Analysis, w.X. Norton 5 Can New York. 1950.

12. Grinder, Poy, Psychosomatic Pesearch, W.W. Norton, Now York, 1957.

13. Jackins. Harvey, Elementary Counselors handbook. Rational Island Publishers, Seattlo, 1962.

14. Jackins, Harvey, Human Stde of Human Beings, Retional Island Piblishars, Seattla, 1970.

15. Jacobson, Fdrund, hodern Treatment of Tense patients, Charles C. Thonas, Fublishar, Springfield, III.. 1970.

16. Janov, Arthur, Erinal Screan, Del.1 Publ. New York, 1970.

17. Lachman, Sheldon, Esychosonat1e D3 sorders - A Zehaviorist Interestation, John is IAY k Sons, Ner York, 1972 . 
Books contirued

18. Parnoll, R.W., Modern Trends in Psychosomatic Medicine, Paul Hoober, Iȟc.. Now York, 1955.

19. Sequin. Cherles. Introduction to Fsychosomatic Medicine. Intl. Univerities Press, 1950, New York.

20. Sharvon, I.J.. Abreaction Therayy of Fsychosomatic DisordersNodern Trends in Psychosomatic padicine, Pal Hoeber. Now York. 1955.

21. Stein, Calfert, Practical Psychotherapy in Non Fsychiatric Specialites, Charles Thomas, Pub.. Springfield, Ill.. 1969.

22. Sullivan, A.J. Personality in Peptic Ulcers, Charles Thomas, Springfield, III., 1950.

23. Weiner, H. Atvances in Psychosomatic Medicine-Duodena? UI Cer. Skang ror Fublishor, Basel, Switz.. 1971.

24. Weiss, Edward, Engl1sh, Spurgeon, Psychosomatic Medicine. W.P. Sauders, Co. Fhiladephia, 1957.

25. Wells, Charles, Peptic Ulceration, E.S. Ifvingstone,Ltd.. adinburgh, 1960.

26. Winters, J.A., Origins of Illness and Anxiety, Julian Press, New York, 1970.

JOIRNALS

27. Abowd. Thomas, "Peptic Uleer- Theory and Therapy", Univ. of Michtgan Cant Journat, Nay-june 1964, op 91-101.

28. Alexander. Franz, "The logic of Imotions and its Dynamic Background" Intl. Journal of Psychoanalysis. 1934.

29. Augur, N.A.. "Now Therapeutic Agents for Peytic Ulcer." J. Majne Mod. Assoc. 64:245-6 Det 19?1.

30. Bauer, J.. Aschner. 5. "Conetitution and Family with Poptic Jlcer". K1n. Wschor. 1922:1:1250.

31. Baugh. V.S.. "Psychological factors in Ulcer Patients." Diseases of Ner. System. 25:553-7, Sept. 1964 .

32. Elumenthal. I.S., "Digestive Disease as a National Problem". Gastroentarology. $54: 86-92$, dan 1968.

33. Bralow, St, "Currant Maragenent of Peptic Ulcer Disases", Del. lod Journal. 44:179-8? Juiy 1972. 
journals contirued

34. Brown, H. et al. "Fersonality Traits of the Peptic Ulcer Fatient," Fsychosomatic Medicino, 12:1: 1956.

35. Chernov, Merrill, "Prevention of Stress Ulcers," Am. J. Surzery. $122,674-7$, Nov. 1971.

36. Cleave, J.L., "Peptic Ulcer-an entirely new approach based on human ovolution". J. Applied Nutrition, 17:43-7 1964.

37. Cox, A.G., "Current Trends in Surgery". Mod. Trends Surg. $3: 46-68,1971$.

38. Crawford. F.A.. "The Stress Ulcer Syndrom", Am. J. Surg.. $121: 644-9$ June 1971 .

37. Jppingar. S.. Hess, L. "Vagotina". Nerve and Mental Disease. monthly series $\$ 20,1915$.

38. Fly, N.E., Johnson, M.H.. "Enotional Response to Feptic Ulcer Management". Amer. J. Fsychiatry, 122:1362-71. June 1966.

39. Flynn. W. E. "Managing the emotinal aspects of peptic ulcers and ulcorative colitis." Post Grad Mod. 47:119-22 May 1970.

40: Franz, M.. "Socie-psychologleal aspects of feptic Ulcer". Journal of Psychosomatic Research, 1:68-74.

41. Gambill, . ... "Treatment of Feptic Ulcers", Minn. Med. 54:628-9. Augusts 1971 .

42. Gibbs, D.D., "Faptic ulcer- advances In Diagnosis", Eritish Med. Journ., 4:99-100, Oct. 1969.

43. Gitelson, Nax, "A critique of current concepts in Psychosonatic. medicine", Eull. of Nenninger Clinic, XXIII 1959, p134-53

44. Glirschowitz, 3.I. "Wianagement of Peptic Ulcer", G.F., 30:105-9. Nov. 1964.

45. Greenacre, Fhyllis, "Fmotional Growth: Fsychoanelytic Studies of the gifted and a great Variaty"Intl Univ. 1971.

46. Grossiar, V.W., "Nanagemant of the uncomplicated reptic Ulcer." Med, CIin of N. America, 45:1459-67, 1961.

47. Grossman, l.I., "A critical anaiysis of various therries of pathoganesis of Paptic Ulcers" in Peptic Ulcer, edt. DT Sandweiss, W.E. Saunders and co, Fhil, 1957, p. 165.

49. Grossman. N.I., "The naed for non-braakthrough in the study of Feptic "leor", New Englayd J, Ned.. 28:43-4, July 3. 1969. 
Journals continued

50. Hamilton, M., "A psychoanalytic investigation of the peptic ulcer personality" Intl Corgress of Fsychology, 1951 Stockholm.

51. Hardwick, C., "Feptic Ulcer Problems". Practitioner, 198,345-50, March, 1967.

52. Harr1s, I.J.. "Mood, Anger and Somatic Dysfunction". Journal of Nervous and Mental Disorders. 113:152-8.

53. Hock, 6.W.. "Paptic Ulcer, a curse of Modern Civilisation". Amer. J.Clin. Nutrition, 15:223-6, Dot 1964.

54. Federson, W.Hojer-, "Observations on Duodenal Ulcers adultted to a Psychiatric Untt", Danish Nod Bull.. 1959:6:50.

55. Jones. F.A. "Clinical and Social Problems of Foptic Ulcer", Brti. Med. J. 195?:I: 719.

56. Kasanen, A. "Social Stress and living habits in the etiology of Peptic Ulcar". Annales, Med. Internae, Fenniee.55:13-22 1966.

57. Kay, AW. "Management of Foptic U, cer" Scot Med J,13,110-15, Ap 1968.

58. Kimbal1, S. "Kereditary and Peptic Ulcer" in Feptic Ulcer, DV Snadwelss, ed. W.B. Sauders CO. Phil 1957, p. 146.

59. Kirsner, J.B. "Facts and fallacies of current medical therapy for uncomplicated duodenal ulcer". JANA, 187:423, 1964.

60. Langman. M.J."Modern Drug Treatment for Poptic Ulcar," Froc. Royal Soc Med. 64:741-2 july 1971.

61. Iangman, M.J.. "Foptic Ulcer Management", Brit. Med J. 4:100-2 Oct. 11. 1969.

62. Iewls. B.I. "Fsychosomat1c process in outpatients", JAMA. 150.776-80, Oct 25. 1952.

63. Nikha11, AA, Holland, MĆ. "A simpl1es ed method of Inducing stomach ulcer". J. of Psychosonatic Research, vol 9. P 343.

54. Mirsky. IA, "Fhysiologie, psychologic and social determinants of the atiology of duodenal ulcex". Amer. J Dig. Disease. $3: 285-314$.

55. N1ttelman, B.. Wolf, H. Scharf, H. "Experimental studies on patiants with gastritis, drodenitis, and peptic ulcer". Isychosonatic Mai, 1942.

66. Necheler. H. "A thaory of the fornation of Foptic Uicer" Amar. 2. Dig Disease. 1937:4:643. 
67. Orge], Z.Z. "Iffect of psychoanalysis on the course of peptic Ulcers," Psychosomatic Medicine vol XX, H2, 1958 p117-23

68. Palmer, פ. "Fenign Gastric Ulcer". Amer. J. of Gestroenterology, $39: 91963$.

69. Porkel,LL. " "Nedical treatment of Poptic ulcer". J. Med. Soc of Now Jorsey, 65:242-8 June, 1965.

70. Rioker, H.H.. "Peptic ulcers in Identical twins", Ann Intern Med. $1946: 24: 878$.

71. Rutter, Michael. "Psychasocal factors in the short term prognosis of physical disease." J. of Psychosomatic Research, 1963, vol? p $45-60$.

72. Savitt, R.A. "Transferencs, sonitiation, and symbiotic need", J. Amer. Psychoanalytic Ass, 17:1030-54 0et, 1969.

73. Schoff. Thomas, "Re-evaluation counseling- a per cathartic therapy" unpublished. Univ of Calif. 1972.

74. Scheff. Thomas, "Re-ovaluation counseling: soclal implications" Journel of Humanistic Psychology. Sprinz 2972, p 58-71.

75. Schlicks. C.F." "Lessons learned from use of Vagotomy" Amer J of Surgery. 124,121-6 Aug 1972.

76. Silverstone, Stanley, Kissinger, Ben, "Field dependence in essential hypertension and peptic ulcer", J. of Fsycho somatic Ressarch, vol. 12, \#2, Aug. 1969.

77. Sperling. M. "Transferance Neurosis in patients with psychosomatic tisorders", Fsychomalytic Quarteriy. 36:342-55.

78. Somers. Bernard, "Re-evaluation therapy-theoretical framework", Journal of Humanist1c Psychology. Spring 1972, 42-7.

79. Stenbacks. A.I. "Person lighet och knnflict vid ulcus duodenum", Finska Lak-Sallsk Handle, 1957:100:187.

80. Stevenson. In, Nathew3, Robert, "Fact and thebry in Psychosomatic medicine," Journal of nervous and Mental Diseases. Oct 1953, vol. 113 H F. 289.

81. Sussner, M. Stein. 2, "Civilination and peptic ulcer" Lancet 1962. $1,115$.

82. Symonds, Percival, "A comprehersive theory of psychotherapy". Aner. J. of Orthopsychiat:y, 1954, p 697-712.

83. Tanner, N.C. "Tha care of peptic ulcer patiants", Bristol Nadicochir. $4.84: 179-84$ Cet 1969. 
84. Van Baker, G.F. "The role of the internist in the psychosocial approach to peptic ulcers". ACTA Psychoter. 1955:3,259.

85. Weiss. J.M. "Psychological factors in stres and Disese". Sc1. Amer. 226:104-13 June 1972 .

86. Wolfe, Harold, "Frotective reaction patterns and disease". Annals of Internal Med. vol 27, 1947, p 944-69.

87. Wrotmark, Gerdt, "Mental and Psychosomatic morbidity in poptic ulcer familles" Journal of Psychos. Research, Vol 5 p. 21-31.

88. Zollinger, R.M. Etal. "Straight talk about Feptic Ulcer". Post Gred. Med. J.. 45,160-4 June 1969.

non authored journals

89. "Mind and Ulcer". Brit Med J.. 31374. Aug 16, 1969.

90. "Psychosomatic aspects of peptic ulcer". Practitioner, 209:104113. June 1972.

91. "10,000 Peptic Ulcer Cases". Isr. J. Hed Sc1., 8:1673-9 Oct. 1972.

92. "Symposium - what's now in treatment of peptic ulcor". British J. of Surgery. 57:779-92 Dctober, 1970 . 


\section{FOOTNOTES}

1. Alexander, Franz, Studies in Psychosomatic Medicine, Ronald Press, New York, 1948.

2. Sequin, Charles, Introduction to Fsychosomatic Medicine. Inter national Univarsities Press. New York, 1950.

3. Alexander op. cit.

4. Lew1s. B.I. "Psychosomatic Frocess in outpatients", JAMA. oct. 25, 1952, 150:776-80.

5. Alexander, op. cit.

6. Dunbar, Flanders, Mind and Body . Random House, NY, 1955.

7. Orgel, S.Z., "gffect of Fsychoanlysis on the course of Peptic Ulcer" Fsychosomatic Med. Vol XX. \#2, 1958 p 119.

8. Alexander op, cit.

9. Wainer, H. Advances in Fsychosomatic Madicine, Duodenal Ulcers Skanger Fublish. Basel, 1971.

10. Harr1s, I.J.. "Mood, Anger and Somatic Dysfunctloning", Jof Nervous and Kent. Disorders, 113,152-8, 2951.

11. Sequin, op cit.

12. Mittelman, Wolff, Scharff. "Exporimantal Studies on Patients with Gastritis, Duedentis, and Feptic Ulear" " Psychosomatic Mod. 1942 .

13. Davies $\&$ Nison. "Observation on the Iife history of Chronic keptic ulcer" Lancet 1937.

14. Bauer \& Achner. "Constitution and Family with Feptic Ulcer" KIIn Weschr 1922:1:1250.

Paderson, Hojer. "Observations on Duodenal Ulcers" Dan. Ned Eu11. $1959: 6: 50$.

15. Rioker, ift "Poptic Ulcer in Identical Twhs" Ann Intern Ned $1946: 24: 878$.

16. Hecheler. H, "Atheory on the formation of paptis ulcer". Ain J Dig Dis, $1937: 4: 643$.

17. Flexander, 5ran, Psychosomatic Specificity, Univ of Chicago Frass, Chicago, 1968.

Dunbar, op. cit.

18. Duribar, op. eit. 
19. Blumenthal. IS, "Digestive disease as a national problen" Rand Gastroenterology $54: 86-92$ dan 2968.

20. "Mind and Ulcer" Brit Med J. $3: 374$ Aug 16, 1969.

21. Bauer and Aschnor, op. cit.

22. Mirsky. IA "Determinants of the otiology of peptic ulcer" Am J of Dig. Dis. 3,285-314.

23. Aboud. Thomas, "Peptic Ulcer, theory and practice" Univ Mich Mad Con J. 30:91-101 May June 1964.

24. Elumenthal op cit.

25. Crawford, FA "The stress Ulcer Syndrom" Am J. Surg, 121:644-9.

26. Blumenthal op. cit.

27. Blumenthal. IS, Research and the Ulcer Problem. Rand Corp. LA 1960.

28. Grinder, 只y, Psychosomatic Research, Wh Norton , NY 1957.

29. Alexander, op. cit.

30. Sussner and Ste1n, "Civilization and Foptic Ulcar, Lancet, 1962. 11:115/6.

31. Weiss, JM, "Fsychologicel Factors in stress and disease" Sci Amer 226:104-113 tune 1972.

32. Mikha11. AA, "Asimplifiad wothod of Inducing stomach ulcer" Journal of Esychosomatic Resoarch, vol $9 \mathrm{p} 343$.

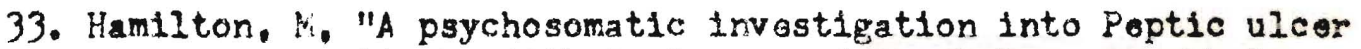
personality", 13th Intl Corie of Fsychology Stockholm.

34. Stlverstone and Kissinger "Field dependencein Feptic Ulcar" Journal of Psychosmatic Research Aug 1968 vol 12 \#2.

35. Brown et al "Fersonality traits of the peptic uicer patient" Psychosom Med 12:1: 1956.

Orgel of eit.

36. Weiss. Sd. Psychosmatio Hedicine. AP Sauders, Fhil. 1957.

37. Jongs 5. "Clintca" and Sorial Prolews of Peptic ulcer" Bvit rad i. 195:J: 718

38. Harris op cit.

39. Flynn, We "Maraglng the emotinal aspacts of Feptic Ulcer" Fostgrad Med $471199-22 \mathrm{Key} 1970$. 
40. Baugh ot al "Fsychological. factors in Ulcer Fatients"

Dis Norv Sys, 25:553 7 Sept 1964.

41. Stenbacks, AI "Fergon lighet och Konflict vid ulces duodent" Finske lak-sallsk 1957-100:187,

42. Wly and Johnson. "3motional response to Popt1c ulcer management" Amer J Psychia. 122:1362-71 June 1966.

43. Alexander op cit.

44. Greenacre. Phyllis, Emotional Growth. Intl Univ. Fress, 1971.

45. Sauer and Aschner, op. eit.

46. Grossman, MI "The nesd for non-breakthrou in peptic ulcer" Naw Ene. J Mad. 28:43, July 3. 1969.

47. Ruttar, Pichal. "Psychosocail. Factors in the short term prognosis of diseas" i of Psychosom es. 7:48.

48. Wrotmark. Gerdt, Mental and Fsychosmatic Morbidity in Feptic ulcar fandica" $y$ of Psychosom Pes 5:21-31.

49. Gambi12. ZE "Tratment of Poptic Ulear" Ninn Had 54:628-9.

50. Ssquin, op, cit.

51. Gibbs, DD. "Feptic Ulcer Advances in Diagnosis" Brit Med J 4:99-100. Dot 1969 .

52. Forkl, LI. "Wedical traetment of poptic ulcar" J Med Seo NJer $65: 242-8$. Juns 1968 .

53. Exalow, SP, "Current managament of Foptic Ulear" Del Moc J 44:179-87 suly 2972.

54. Hock, Cr "Feptic ulcar, a curso of modarn civilization"An J Cin Nutrition, 15:223m6 Oct 1964 .

55. Bralow, op. clt.

56. Zollinger at al "Straight talk about peptic ulcars" Fostgrad ied. $45: 560-4$ June 1959.

57. Langman, WJ "artio Wloer madical treatment"Brit Yod J $4: 100-2$. 00 . 11. 1969 ,

58. Weiner, op. at.

59. Chernov, ". "rovention of stress ulcers" Am J Sure 122:674-7, Nov "71.

50. Eralow, op. $: \pm t$. 
61. Elly and Johnson, op cit.

62. Schlicks, CF "Lsssons learned from use of Vsgotomy" Am J Surg 124:121-6 Aug 1972 .

"Symposium-whats now in treatment of peptic ulcer"Brit $J$ hed 57-779-92, oct 1970 .

Cox, AG "Current trends in Surgery" Mod Trends Surg 3,46-68 19 .

63. Hock, op. c1t.

64. Blumenthal. Research op cit.

65. Savitt. FA "Transference, somitazation and symbiotic need" J Amer Psychoanal Assoc, 17:1030 -4 oct 1969.

66. Paloer, E, "Eanign Gastric Uicer" Am J Gastro-ent.39-9 1963.

67. Sequin, op ct?.

68. Brouer. Josef, Freud, Stgmund, Studies on Hysteria. Basic Eodks NY $195 ?$.

69. Wolff, Harold, "Protectiva reaction pattarn and disease" Ann Intarn Med 27:9444-69 1947.

70. Darwin, Charles, Expression of Emotions in Man and Animals Apploton and Co, NY 1896 .

71. Brever, of, cit. p 71.

72. Alexandar, op cit. p.11.

73. Brouer, op. cit.

74. 1bid. $p 217$.

75. Alexandar, F'sychosomatic Spgeificity or cit.

76. Alexandar, op cit. p 107.

77. St venson f Nathors. "Fact and theory in psychosomatic medicing" J Nerv and Ment Dis, Oet 1953, 113:4, 289.

78. Sulliran, A.J. Sersonality in Feptic Ulcers, Charles Thoras, Springis ald. 1960.

79. Eargh et al, op cit.

80. Grirder, op, cit.

81. ibjd.

82. Duntar, op cit. 
83. Grinder, sp. cit. and ibid.

84. Grinder, op c1t.

85. Dunbar, op e1t. p 169.

86. Wolff, Herold op, cit.

Mittelman, wolff, Scharff op cit.

87. Sequin, op. eit.

88. Deutsch, F., Mind, Body and the sensory Gatoways Basic Books, IX 1963.

89. Lachman, Sheldon, Psychosomatic Dlsorders- Behaviorist Interpretation, John Wiley \& Sons, NI, 1972.

90. Hbid. p 189.

91. Jackins, Harvgy, Human Side of Human Eeings, Rational Island Press Seattle, 1970.

92. Brouer, op cit.

93. 1bid.

94. Alexander. op. c1t.

95. Alexander, op. cit, p 11.

96. Dunbar, op, cit.

97. Sharvon. IJ, "Abreaction Therapy of Psychosomatic Disorders" from Modern Trends in Psychosomatic liedicine, O'ilesi, D ed. Paul Hoober Pub.. NY 1965.

98. Harris, op, c1t.

99. Mittelmar, Wolff, Scharff op. cit.

100. Grennacre, op cit.

101. Mirsner, JB."Facts and Fallacies of Duoderal Ieors", JAMA $1964,187: 423$.

102. Symonds. Percival, "A comprehensive thoory of peychotharapy" Am i of Orthopsychiatry 1954, $69^{m}-712$.

103. Jackins, Harvay, Ilementary Counselors Handbood. Fational Island Press, Seettle, 1962.

104. Scheff, Thomas, "Ro-evaiuation Counseling-Social Implicationt" Jof Huranistic Esych. Spring 1972 . 58-71. 
105. Somers, Bernard, "Re-evaluation co-counseling therapy- Theoretical Framework". J. of Humanistic Psych. Spring 1972, 42-57.

106. Scheff. Thoms, "Femevaluation comcounseling- a peer cathartic therapy" unpublished. $19 ? 2$ univ of Calif.

107. Brouer, op. cit.

108. Scheff, op. cit.

109. Brouer, op. cit.

110. Janov, Arthur, Primal Scresm, Dall, NY., 1970.

111. 1bid. p 254 .

112. ibid. p 254 .

113. Scheff, of. eit. 